\title{
HUBUNGAN ANTARA MOTIVASI PADA IBU NIFAS \\ UNTUK MENYUSUI BAYINYA DENGAN KEJADIAN BENDUNGAN ASI \\ (Studi Di BPS Yuliana, Amd. Keb. Kabupaten Lamongan 2016)
}

\author{
Husnul Muthoharoh*
}

*Dosen Program Studi D III Kebidanan Universitas Islam Lamongan

\begin{abstract}
ABSTRAK
Bendungan ASI merupakan pembendungan air susu karena penyempitan duktus laktiferus atau kelenjar - kelenjar payudara tidak dikosongkan dengan sempurna atau karena kelainan pada puting susu. Dengan adanya motivasi dari Ibu dan dorongan dari suami atau keluarga diharapkan ibu mau menyusui bayinya sendiri, sehingga ibu bisa memberikan ASI dan tidak terjadi bendungan ASI.

Desain penelitian adalah analitik dengan pendekatan cross sectional. Sampel yang digunakan sebanyak 24 ibu nifas diambil dengan cara random sampling. Variabel independennya adalah motivasi sedangkan variabel dependennya adalah kejadian bendungan ASI. Data diambil dengan menggunakan kuesioner dan lembar check list. Dan dianalisis dengan tabel data menggunakan uji koefisien phi.

Dari hasil penelitian ini menunjukkan bahwa responden yang mempunyai motivasi baik hampir seluruhnya tidak terjadi bendungan ASI dan responden yang motivasinya kurang hampir bisa terjadi bendungan ASI. Didapat hasil dengan $\mathrm{X}^{2}$ hitung (Value) $=4,854$ dan $\rho=0,02$. Kemudian bila $\rho \leq \alpha(0,02 \leq 0,05)$ dan $X^{2}$ hitung $\geq X^{2}$ tabel $(4,854 \geq 3,481)$.

Kesimpulan dari penelitian ini adalah ada hubungan antara motivasi pada ibu nifas untuk menyusui bayinya dengan kejadian bendungan ASI.

Diharapkan bagi ibu nifas untuk mempunyai motivasi dalam menyusui bayinya dan diharapkan bidan sebagai tenaga kesehatan serta pihak keluarga, terutama suami mampu memberikan perhatian pada ibu agar mau menyusui bayinya.
\end{abstract}

Kata Kunci: motivasi, nifas, bendungan ASI. 


\section{PENDAHULUAN}

Bendungan ASI merupakan pembendungan air susu karena penyempitan duktus laktiferus atau kelenjar - kelenjar tidak dikosongkan dengan sempurna atau karena kelainan pada putting susu (Mochtar, 1998). Motivasi pemberian ASI diartikan sebagai suatu sikap penciptaan situasi yang merangsang kegairahan ibu-ibu untuk memberikan ASI pada bayinya, sehingga dapat terciptanya manusia yang berkualitas dan berdaya saing yang tinggi untuk menyusui. Terutama motivasi dari keluarga dan suami sangat diperlukan. Keluarga yang selalu memberi pujian, semangat dan dorongan agar ibu bisa percaya diri untuk menyusui. Sehingga hal ini akan menimbulkan sikap yang positif bagi ibu untuk melaksanakan tugas barunya dalam memberikan cairan yang sangat berharga untuk bayinya. Walaupun ASI belum keluar, ibu tetap berusaha menyusukan bayinya untuk menghindari kejadian bendungan ASI (Soetjiningsih, 1997).

Menurut penelitian terjadinya bendungan ASI di Indonesia terbanyak adalah pada ibu-ibu pekerja, sebanyak $60 \%$ dari ibu yang menyusui (Depkes, RI, 2006). Berdasarkan survey tahun 2002 oleh Nutrition and Health di Jawa Tengah tentang ibu yang memberikan ASI pada bayinya, di perkotaan hanya 1 3\% (1-3 kejadian bendungan ASI dari 100 ibu yang menyusui) dan di pedesaan $2-13 \% \quad$ (2-13 kejadian bendungan ASI dari 100 ibu yang menyusui) (Depkes, RI 2006).

Berdasarkan dari survey awal di BPS Yuliana, Amd. Keb Kabupaten Lamongan pada bulan Oktober-November 2015 terdapat 11 ibu nifas, yang terdiri dari ibu nifas primipara sebanyak 7 orang dan multipara 4 orang. Dari 7 orang ibu nifas primipara terdapat $70 \% \quad(5$ orang) ibu nifas tidak melakukan pemberian ASI pada bayinya dan $30 \%$ (2 orang) ibu melakukan pemberian ASI pada bayinya. Dari $70 \%$ (5 orang) pada ibu yang tidak melakukan pemberian ASI 60\% (3 orang) terjadi bendungan ASI dan $40 \%$ (2 orang) tidak terjadi bendungan ASI.

Terjadinya bendungan ASI pada ibu nifas disebabkan beberapa faktor yaitu faktor internal meliputi faktor fisik, psikis, pekerjaan, pengetahuan, keinginan dalam diri sendiri (motivasi) dan pengalaman. Faktor eksternal meliputi faktor bayi, lingkungan, sosial budaya, dan motivasi dari berbagai pihak baik dari keluarga, tetangga maupun dari petugas kesehatan sendiri (Handoko, 1998). Kebanyakan ibu nifas primipara masih nampak kaku dan mempunyai rasa cemas untuk melakukan pemberian ASI pada bayinya. Ketika penulis menanyakan kepada 5 ibu nifas primipara tersebut ternyata mereka tidak bisa menyusui bayinya sendiri. Mereka beralasan malas, takut dan bingung pada anak kecil (bayi baru lahir) terutama bila bergerak dan menangis sehingga mereka membiarkan bayinya diasuh oleh ibu kandungnya sendiri atau mertuanya. Selain itu nampaknya para ibu nifas jaman modern ini memiliki kecenderungan yang lebih sibuk bekerja dan takut bagian tubuhnya berubah karena menyusui bayinya.

Upaya yang dapat dilakukan oleh petugas kesehatan untuk mencegah terjadinya bendungan ASI adalah dengan memberikan motivasi kepada ibu nifas agar mau melakukan pemberian ASI pada 
bayinya secara dini. Disini dorongan dari keluarga juga sangat dibutuhkan. Salah satu asuhan yang dapat diberikan adalah Inisiasi Menyusu Dini atau disingkat sebagai IMD merupakan program yang sedang gencar dianjurkan pemerintah. Menyusu dan bukan menyusui merupakan gambaran bahwa IMD bukan program ibu menyusui bayi tetapi bayi yang harus aktif menemukan sendiri puting susu ibu. ASI eksklusif selama 6 bulan (sedikit lebih lama diperkenankan pada keadaan bencana saat risiko penyakit menular cukup tinggi). Makanan pendamping dimulai dari usia 6 bulan dengan jumlah yang sesuai dan cukup.

\section{TUJUAN PENELITIAN}

Mengetahui hubungan antara motivasi pada ibu nifas untuk menyusui bayinya dengan kejadian bendungan ASI di BPS Yuliana, Amd. Keb. Kabupaten Lamongan 2016.

\section{METODE PENELITIAN}

\section{Desain Penelitian}

Desain penelitian ini adalah jenis penelitian analitik dengan Studi Korelasional, yaitu suatu penelitian yang mengkaji hubungan antara variabel. Peneliti dapat mencari, menjelaskan suatu hubungan, memperkirakan, menguji berdasarkan teori yang ada. Berdasarkan waktu penelitian menggunakan cross sectional dimana jenis penelitian yang menekankan pada waktu pengukuran atau observasi data variabel independen dan dependen hanya satu kali pada satu saat, jadi tidak ada follow up (Nursalam, 2008). Dengan demikian desain dalam penelitian ini adalah mengetahui hubungan antara motivasi pada ibu nifas untuk menyusui bayinya dengan kejadian bendungan ASI.

\section{Waktu dan Tempat}

Penelitian ini dilakukan pada bulan Januari sampai dengan Agustus tahun 2016 di BPS Yuliana, Amd. Keb. Kabupaten Lamongan.

\section{Populasi dan Sampel}

Populasi pada penelitian ini populasinya adalah ibu nifas di BPS Yuliana, Amd. Keb. Kabupaten Lamongan pada bulan Januari - Juni 2016 sebanyak 25 responden. Sampel dalam penelitian ini adalah ibu nifas di BPS Yuliana, Amd. Keb. Kabupaten Lamongan 2016 sebanyak 24 responden.

Berdasarkan populasi diatas, maka besar sampel ditentukan dengan rumus :

$$
n=\frac{N}{1+N\left(d^{2}\right)}
$$

Keterangan :

$\mathrm{n}=$ Jumlah sampel

$\mathrm{N}=$ Jumlah populasi

$\mathrm{d}=$ Tingkat signifikansi $(\mathrm{d}=0.05)$

Maka jumlah sampel ditentukan

$$
\begin{aligned}
& n=\frac{25}{1+25\left(0.05^{2}\right)} \\
& n=\frac{25}{1.0625} \\
& n=23.5 \\
& n=24 \text { responden }
\end{aligned}
$$

\section{Teknik Pengambilan Sampel}

Teknik sampling yang digunakan dalam penelitian ini adalah probability sampling dengan teknik simple random sampling (acak atau lotre). Dengan cara yaitu penyusunan daftar populasi, menghitung besar sample dan 
wilayah kerja, membuat nomer undian, mnengambil undian sebanyak hasil perhitungan sampel.

\section{Cara Pengumpulan Data}

Pengumpulan data adalah suatu proses pendekatan kepada subjek dan proses pengumpulan karakteristik subjek yang diperlukan dalam suatu penelitian (Nursalam, 2008). Data dikumpulkan melalui kuesioner pada ibu nifas di BPS Yuliana Kabupaten Lamongan yang memenuhi kriteria inklusi.

\section{Pengolahan dan Analisa Data Teknik Pengolahan Data}

Data yang telah diperoleh kemudian dilakukan pengolahan sebagai berikut:

\section{Editing}

Editing data yang dilakukan meliputi mengecek kelengkapan identitas dan format pengumpulan data apakah sudah cukup baik sebagai upaya menjaga kualitas data agar dapat diproses lebih lanjut

\section{Coding}

Coding adalah melakukan pengkodean data. Untuk memudahkan pengolahannya semua jawaban atau data tersebut disederhanakan dengan cara memberikan simbol-simbol tertentu untuk setiap jawaban tersebut.

1) Variabel independent (motivasi pada ibu nifas untuk menyusui bayinya )

Motivasi baik $=1$

Motivasi kurang $=0$

2) Variabel dependent (kejadian bendungan ASI pada ibu nifas)

Tidak terjadi bendungan ASI $=1$

Terjadi bendungan ASI $\quad=0$

3. Scoring

Scoring adalah dengan memberikan skor pada jawaban untuk pertanyaan positif jika ya nilainya : 1 jika tidak nilainya : 0 , untuk pertanyaan negatif jika ya nilainya : 0 jika tidak nilainya : 1 . Skor untuk variabel indepentent (motivasi pada ibu nifas untuk menyusui bayinya) adalah baik jika skor (56-100\%) dan kurang jika skor (< 55\%). Menentukan score/nilai untuk item pertanyaan dan menentukan nilai terendah dan tertinggi. Jawaban benar diberi skor 1 dan jika jawaban salah diberi skor 0 .

\section{Tabulasi Data}

Tabulasi adalah proses penyusunan data ke dalam bentuk tabel, pada tahap ini data dianggap telah selesai diproses sehingga harus segera disusun ke dalam suatu format yang telah dirancang.

\section{Analisa Data}

1. Analisa Univariat

1) Motivasi ibu

Cara mengukur motivasi ibu nifas dengan lembar kuesioner 15 pertanyaan. Rumusan yang digunakan yaitu menjumlahkan nilai tiap responden kemudian dibagi skor tertinggi dikalikan $100 \%$.

$$
\mathrm{N}=\frac{\mathrm{Sp}}{\mathrm{Sm}} \times 100 \%
$$

Keterangan :

$\mathrm{N} \quad$ : Presentase yang dicari

Sp : Skor yang diperoleh

SM : Skor tertinggi

Hasil persentase kemudian diinterpretasikan dengan modifikasi kesimpulan menurut Suharsimi Arikunto (2006), sebagai berikut:
1). $100 \%$
: Seluruhnya
2). $76-99 \%$
:Hampir

seluruhnya

3). $51-75 \%$ : Sebagian besar

4). $50 \%$

:Setengah atau

sebagian

5). 26-49\% : Hampir setengah

atau sebagian
6). $1-25 \%$
: Sebagian kecil
7). $0 \%$
: Tidak satupun 
Setelah diketahui kemudian hasilnya dikelompokkan menurut Arikunto (2003) yang mengklasifikasikan motivasi dalam 2 kategori :

(1) Tingkat motivasi baik : 56 $100 \%$ kode 2

(2) Tingkat motivasi kurang : > 55$100 \%$ kode 1

2) Bendungan ASI

Cara mengukur terjadi bendungan ASI apabila pada saat dilakukan pemeriksaan sesuai lembar observasi responden dan memenuhi kriteria terjadinya bendungan ASI :

- Payudara teraba keras

- Payudara pada perabaan terasa nyeri

- ASI tidak keluar

- Panas badan suhu $37,6{ }^{\circ} \mathrm{C}-39^{\circ} \mathrm{C}$

Nilai didapatkan dengan rumus :

$$
\mathrm{n}=\frac{\text { Skor maksimum }- \text { Skor minimum }}{\text { Kategori }}
$$

$$
\begin{aligned}
& =\frac{40-10}{2} \\
& =15
\end{aligned}
$$

Bila nilai $\leq 25$ tidak terjadi

bendungan ASI kode 2

Bila nilai $>25$ terjadi bendungan ASI kode 1

\section{Analisa Bivariat}

Data sudah terkumpul ditabulasi kemudian jawaban yang sama dikelompokkan dalam tabel distribusi frekuensi, mengingat penelitian ini bertujuan untuk mengetahui hubungan dari dua variabel yaitu : Hubungan antara motivasi ibu pada ibu nifas untuk menyusui bayinya dengan kejadian bendungan ASI di BPS Yuliana, Amd. Keb Kabupaten Lamongan 2016. Dimana variabel independen menggunakan skala nominal dan variabel dependen menggunakan skala data nominal, maka analisis dilakukan uji statistik dengan Rumus Koefisien korelasi phi yang menggunakan sistem SPSS (Statistical Product and Service Solution) versi 17.0 for windows dengan tingkat kemaknaan $(\alpha)$ yaitu 0,05 .

Untuk mengetahui adanya hubungan antara motivasi pada ibu nifas untuk menyusui bayinya dan kejadian bendungan ASI dilakukan uji statistik dengan menggunakan Koefisien korelasi phi.

Koefisien korelasi phi merupakan ukuran keeratan hubungan antara 2 tabel dengan skala nominal yang bersifat dikotomi (Usman, 2006 dan Sutrisno, 2005).

Nilai korelasi yang dihasilkan berkisar antara 0 sampai dengan 1 . angka pada nilai korelasi menunjukkan karena keeratan hubungan antara 2 variabel yang diuji. Jika angka korelasi makin mendekati 1, maka korelasi 2 variabel akan makin kuat, sedangkan jika angka korelasi makin mendekati 0 maka korelasi 2 variabel makin lemah.

Sifat hubungan kedua tabel yang diuji, tidak dapat ditunjukkan dari nilai korelasi phi, karena dua tabel yang diukuir mempunyai skala nominal.

Untuk uji signifikasi, diperlukan pembentukan hipotesis sebagai berikut :

1. $\mathrm{H}_{0}$ : motivasi pada ibu nifas dan kejadian bendungan ASI tidak saling berhubungan

2. $\mathrm{H}_{1}$ : motivasi pada ibu nifas dan kejadian bendungan ASI saling berhubungan

Korelasi untuk 2 variabel nominal yang terdiri dari 2 kategori, disebut korelasi phi $\left(\mathrm{r}_{\phi}\right)$ di hitung dengan rumus :

Rumus $r_{\phi}=\frac{a d-b c}{\sqrt{(a+b)(c+d)(a+c)(b+d)}}$ 
Keterangan :

a : data pada baris 1 kolom 1

$\mathrm{b}$ : data pada baris 1 kolom 2

$\mathrm{c}$ : data pada baris 2 kolom 1

$\mathrm{d}$ : data pada baris 2 kolom 2

Apabila : $\mathrm{p}<0,05$ maka Ho ditolak

Apabila : $\mathrm{p}>0,05$ maka Ho diterima

\section{HASIL DAN PEMBAHASAN}

\section{Hasil Penelitian}

1. Karakteristik Ibu Nifas

Berdasarkan Umur

Tabel 1. Distribusi Ibu Nifas

Berdasarkan Umur di BPS

Yuliana, Amd. Keb. Kabupaten

Lamongan Pada Bulan Juni 2016

\begin{tabular}{clll}
\hline No. & Umur & Frekuensi & $\%$ \\
\hline 1. & $\leq 20$ & 2 & 8,3 \\
2. & $21-35$ & 22 & 91,7 \\
\hline \multicolumn{2}{l}{ Total } & 24 & 100
\end{tabular}

Dari tabel 1 di atas diketahui hampir seluruh besar ibu nifas berumur 21-35 tahun yaitu $(91,7 \%)$ ibu nifas dan sebagian kecil berumur $\leq 20$ tahun yaitu $(8,3 \%)$ ibu nifas.

\section{Karakteristik Ibu Nifas}

\section{Berdasarkan Pendidikan}

Tabel 2. Distribusi Ibu Nifas

Berdasarkan Pendidikan di

BPS Yuliana, Amd. Keb.

Kabupaten Lamongan Pada

Bulan Juni 2016

\begin{tabular}{clcc}
\hline No. & Pendidikan & Frekuensi & $\%$ \\
\hline 1. & SMP & 2 & 8,3 \\
2. & SMA & 16 & 66,7 \\
3. & Perguruan & 6 & 25,0 \\
& Tinggi & & \\
\hline & Total & 24 & 100 \\
\hline
\end{tabular}

Lamongan Pada Bulan Juni 2016

\begin{tabular}{clcc}
\hline No. & Pekerjaan & Frekuensi & $\%$ \\
\hline 1. & Tidak bekerja/ IRT & 13 & 54,2 \\
2. & Swasta & 7 & 29,2 \\
3. & PNS & 4 & 16,7 \\
\hline & Total & 24 & 100 \\
\hline
\end{tabular}

Dari tabel 3 di atas diketahui sebagian besar ibu nifas sebagai Ibu Rumah Tangga yaitu (54,2\%) ibu nifas dan sebagian kecil bekerja sebagai PNS yaitu (16,7 \%) ibu nifas.

4. Karakteristik Ibu Nifas

Berdasarkan Motivasi Pada Ibu

Nifas Untuk Menyusui Bayinya

Tabel 4. Distribusi Ibu Nifas

Berdasarkan Motivasi Pada Ibu

Nifas Untuk Menyusui

Bayinya di BPS Yuliana, Amd.

Keb. Kabupaten Lamongan

Pada Bulan Juni 2016

\begin{tabular}{clcc}
\hline No. & Motivasi & Frekuensi & $\%$ \\
\hline 1. & Baik & 15 & 62,5 \\
2. & Kurang & 9 & 37,5 \\
\hline & Total & 24 & 100 \\
\hline
\end{tabular}

Dari tabel 4 di atas diketahui sebagian besar ibu nifas mempunyai motivasi baik yaitu (62,5\%) ibu nifas dan hampir sebagian mempunyai motivasi kurang yaitu $(37,5 \%)$ ibu nifas.

5. Karakteristik Ibu Nifas Berdasarkan Kejadian Bendungan ASI

Tabel 5

Distribusi Ibu Nifas

Berdasarkan Kejadian

Bendungan ASI di BPS

Yuliana, Amd. Keb. Kabupaten Lamongan Pada Bulan Juni 2016

Dari tabel 2 di atas diketahui sebagian besar ibu nifas berpendidikan SMA yaitu $(66,7 \%)$ ibu nifas dan sebagian kecil SMP yaitu $(8,3 \%)$ ibu nifas.

3. Karakteristik Ibu Nifas

Berdasarkan Pekerjaan

Tabel 3 Distribusi Ibu Nifas

Berdasarkan Pekerjaan di BPS Yuliana, Amd. Keb. Kabupaten

\begin{tabular}{clcc}
\hline No. & $\begin{array}{l}\text { Kejadian } \\
\text { bendungan ASI }\end{array}$ & Frekuensi & $\%$ \\
\hline 1. & $\begin{array}{l}\text { Terjadi } \\
\text { bendungan ASI } \\
\text { Tidak terjadi } \\
\text { bendungan ASI }\end{array}$ & 7 & 29,2 \\
Total & 24 & 10,8 \\
\hline
\end{tabular}

Dari tabel 5 di atas diketahui sebagian besar ibu nifas tidak terjadi 
bendungan ASI yaitu (70,8\%) ibu nifas dan hampir sebagian terjadi bendungan ASI yaitu (29,2\%) ibu nifas.

6. Hubungan Antara Motivasi Pada Ibu Nifas Untuk Menyusui Bayinya Dengan Kejadian Bendungan ASI di BPS Yul;iana, Amd. Keb. Kabupaten Lamongan 2016

Tabel 6. Hubungan Antara Motivasi Pada Ibu Nifas Untuk Menyusui Bayinya Dengan Kejadian Bendungan ASI di BPS Yuliana, Amd. Keb. Kabupaten Lamongan Pada Bulan Juni 2016

\begin{tabular}{|c|c|c|c|c|c|c|c|}
\hline \multirow{2}{*}{$\begin{array}{l}\text { No } \\
\text {. }\end{array}$} & \multirow[t]{2}{*}{ Motivasi } & \multicolumn{4}{|c|}{ Kejadian bendungan ASI } & \multirow{2}{*}{\multicolumn{2}{|c|}{ Jumlah }} \\
\hline & & $\mathbf{Y a}$ & $\%$ & Tidak & $\%$ & & \\
\hline 1. & Baik & 2 & 13,3 & 13 & 86,7 & 15 & 100 \\
\hline \multirow[t]{3}{*}{2.} & Kurang & 5 & 55,6 & 4 & 44,4 & 9 & 100 \\
\hline & Jumlah & 7 & 29,2 & 17 & 70,8 & 24 & 100 \\
\hline & \multicolumn{3}{|c|}{$\mathrm{X}^{2}$ hitung $=4,584$} & \multicolumn{2}{|c|}{$\rho=0,02$} & \multicolumn{2}{|c|}{$\alpha=0,05$} \\
\hline
\end{tabular}

Dari tabel 6 di atas diketahui bahwa ibu nifas yang mempunyai motivasi baik hampir seluruhnya tidak terjadi bendungan ASI yaitu $(86,7 \%)$ ibu nifas. Sedangkan ibu nifas yang mempunyai motivasi kurang hampir sebagian terjadi bendungan ASI yaitu (29,2 \%) ibu nifas.

Dari hasil tabel silang diatas untuk mengetahui adanya hubungan antara motivasi pada ibu nifas untuk menyusui bayinya dan kejadian bendungan ASI dilakukan Uji Statistik dengan menggunakan Koefisien korelasi phi dengan tingkat kemaknaan $(\alpha)$ yaitu 0,05 . Berdasarkan hasil analisa data jawaban kuisioner dan lembar observasi (Ceklist) dengan menggunakan desain penelitian analitik dengan tarif signifikan 0,05. Didapat hasil dengan $X^{2}$ hitung (Value) $\quad=4,854$ dan $\rho=0,02$. Kemudian bila $\rho \leq \alpha(0,02 \leq 0,05)$ dan $X^{2}$ hitung $\geq X^{2}$ tabel $(4,854 \geq$ $3,481)$. Maka $\mathrm{H}_{0}$ ditolak yang artinya
Ada Hubungan Antara Motivasi Pada Ibu Nifas Untuk Menyusui Bayinya Dengan Kejadian Bendungan ASI.

\section{Pembahasan}

\section{Motivasi Pada Ibu Nifas Untuk Menyusui Bayinya Tentang Kejadian Bendungan ASI}

Motivasi pada ibu nifas untuk menyusui bayinya tentang kejadian bendungan ASI 24 ibu nifas terdapat $(86,7 \%)$ ibu nifas masuk dalam kategori baik. Motivasi merupakan dorongan dasar yang menggerakkan seseorang bertingkah laku (Hamzah B, 2007). Hal ini disebabkan oleh karena kurangnya keinginan dalam diri ibu untuk melakukan pemberian ASI pada bayinya, dan ibu belum mempraktekkan untuk memberikan ASI pada bayinya sendiri, sehingga ibu selalu mengharapkan dorongan atau diperintah agar melakukan pemberian ASI pada bayinya. Terutama dorongan dan perhatian dari suami dan keluarga.

Hal tersebut juga disebabkan oleh beberapa faktor antara lain umur. Ibu nifas berumur 21-35 tahun yaitu $22(91,7 \%)$ ibu nifas. Pada rentang usia ini kemungkinan pengalaman terhadap aplikasi seharihari terlampaui karena semakin cukup usia, tingkat kematangan akan berkembang secara optimal termasuk didalamnya pengalaman serta kekuatan seseorang dalam berfikir dan bekerja (Nursalam dan Siti Pariani, 2001). Semakin bertambahnya usia dapat mempengaruhi motivasi ibu sehingga perhatian dari suami dan keluarga sangat dibutuhkan supaya ibu mau memberikan ASI secara dini.

Hampir sebagian besar dari ibu nifas berpendidikan SMA 16 $(66,7 \%)$ ibu nifas,sesuai dengan pendapat Koentjaraningrat (1997) semakin tinggi pendidikan seseorang, 
semakin mudah menerima informasi sehingga semakin banyak pula pengetahuan yang dimilikinya atau sebaliknya. Hal ini juga didukung dengan teori Notoatmodjo (2003) bahwasannya semakin tinggi pendidikan maka pengetahuan, keterampilan dan sikap positif akan meningkat pula. Selain itu juga kurangnya kesadaran dalam diri pasien untuk melakukan pemberian ASI pada bayinya. Karena untuk menumbuhkan motivasi dalam diri pasien memang sulit karena motivasi itu timbul dengan sendirinya dalam diri pasien dan tidak perlu dirangsang dari luar.

Hasil penelitian ini menunjukkan bahwa sebagian besar ibu tidak bekerja atau ibu rumah tangga (54,2 \%). Hal tersebut menunjukkan bahwa ibu nifas berperan lebih banyak sebagai ibu rumah tangga, dibandingkan harus bekerja di luar rumah. Dengan demikian diharapkan para ibu lebih mempunyai waktu dalam menyusui bayinya, karena ibu yang bekerja lebih sering tidak mempunyai waktu dalam menyusui bayinya seperti yang dikatakan oleh Nursalam (2001) bahwa pekerjaan bukanlah sumber kesenangan tetapi lebih banyak merupakan cara mencari nafkah yang membosankan, berulang dan banyak tantangan dan bekerja pada umumnya menyita waktu. Ibu yang bekerja mempunyai kesibukan yang banyak sehingga tidak mempunyai waktu untuk menyusui bayinya.

Karena untuk menumbuhkan motivasi dalam diri seseorang memang sulit karena motivasi itu timbul dengan sendirinya dalam diri dan tidak perlu dirangsang dari luar. Penjelasan di atas sesuai dengan pendapat Sardiman (1996) yang menyatakan bahwa motivasi adalah motif-motif yang menjadi aktif dan tidak perlu dirangsang dari luar karena di dalam diri setiap individu sudah ada dorongan untuk melakukan sesuatu.

\section{Kejadian Bendungan ASI}

Kejadian Bendungan ASI dari 24 ibu nifas terdapat $(70,8 \%)$ ibu nifas yang tidak terjadi bendungan ASI, dari ibu nifas tersebut semuanya mempunyai motivasi baik. Hal ini terjadi akibat pengembungan atau peningkatan pembuluh vena dan limfe karena pasokan darah ke dalam payudara akan meningkat sebagai persiapan untuk mulainya laktasi (Farrer, 2001). Jika ibu mempuyai motivasi yang baik dan mempraktekkan dalam kehidupan sehari-hari untuk meyusui bayinya maka ibu bisa tidak terjadi bendungan ASI.

Ditinjau dari pendidikan ibu nifas sebagian besar berpendidikan SMA sebanyak $(66,7 \%)$ ibu nifas. Semakin tinggi pendidikan seseorang, semakin mudah menerima informasi sehingga semakin banyak pula pengetahuan yang dimilikinya atau sebaliknya. Hal ini juga didukung dengan teori Notoatmodjo (2003) bahwasannya semakin tinggi pendidikan maka motivasi, keterampilan dan sikap positif akan meningkat pula.

Hampir seluruhnya ibu nifas berumur 21-35 tahun yaitu 22 (91,7 $\%)$ ibu nifas, Pada rentang usia ini kemungkinan pengalaman terhadap aplikasi sehari-hari terlampaui karena semakin cukup usia, tingkat kematangan akan berkembang secara optimal termasuk didalamnya pengalaman serta kekuatan seseorang dalam berfikir dan bekerja (Nursalam dan Siti Pariani, 2001). Bahwa motivasi seseorang dapat dipengaruh 
umur. Tetapi motivasi dalam diri seseorang sendiri bisa tumbuh dengan adanya dorongan dari keluarga, suami dan petugas kesehatan. Sehingga ibu merasa diperhatikan dan mau menyusui bayinya.

Faktor-faktor

yang mempengaruhi Kejadian Bendungan ASI meliputi faktor internal yaitu fisik, psikis, pekerjaan, pengetahuan, keinginan dalam diri sendiri (motivasi), pengalaman. Faktor eksternal yaitu faktor bayi, lingkungan, social budaya dan motivasi dari berbagai pihak baik dari keluarga, tetangga maupun dari petugas kesehatan (Handoko, 1998).

\section{Hubungan antara motivasi Pada Ibu Nifas Untuk Menyusui Bayinya dengan Kejadian Bendungan ASI Kabupaten Lamongan.}

Ibu nifas yang mempunyai motivasi baik hampir seluruhnya tidak terjadi bendungan ASI yaitu $(86,7 \%)$ ibu nifas. Sedangkan ibu nifas yang mempunyai motivasi kurang hampir sebagian terjadi bendungan ASI yaitu $(29,2 \%) \mathrm{ibu}$ nifas.

Kurangnya motivasi pada diri
sendiri terutama motivasi dari
keluarga dan suami sangat
diperlukan. Keluarga yang selalu
memberi pujian, semangat dan
dorongan agar ibu bisa percaya diri
untuk menyusui. Sehingga hal ini
akan menimbulkan sikap yang positif
bagi ibu untuk melaksanakan tugas
barunya dalam memberikan cairan
yang sangat berharga untuk bayinya.
Walaupun ASI belum keluar, ibu
tetap berusaha menyusukan bayinya
untuk menghindari kejadian
bendungan ASI. (Soetjiningsih,
1997). A

Dari hasil penghitungan Koefisien korelasi phi pada tabel silang menunjukkan bahwa Ho ditolak dan $\mathrm{H} 1$ diterima yang artinya terdapat hubungan antara motivasi pada ibu nifas untuk menyusui bayinya dngan kejadian bendungan ASI.

Hal ini sesuai dengan Faktorfaktor yang mempengaruhi Kejadian Bendungan ASI meliputi faktor internal yaitu fisik, psikis, pekerjaan, pengetahuan, keinginan dalam diri sendiri (motivasi), pengalaman. Faktor eksternal yaitu faktor bayi, lingkungan, social budaya dan motivasi dari berbagai pihak baik dari keluarga, tetangga maupun dari petugas kesehatan (Handoko, 1998).

Menurut pendapat Sardiman (1996) yang menyatakan bahwa motivasi adalah motif-motif yang menjadi aktif dan tidak perlu dirangsang dari luar karena di dalam diri setiap individu sudah ada dorongan untuk melakukan sesuatu.

Banyak teori motivasi yang didasarkan dari asas kebutuhan (need). Kebutuhan yang menyebabkan seseorang berusaha untuk dapat memenuhinya. Perilaku seseorang dirancang untuk mencapai tujuan. Dengan demikian, motivasi merupakan kekuatan yang mendorong seseorang untuk melakukan sesuatu untuk mencapai tujuan. Kekuatan ini pada dasarnya dirangsang oleh adanya berbagai macam kebutuhan, seperti keinginan yang hendak dicapai, tingkah laku, tujuan, umpan balik. Dan dengan adanya motivasi dari Ibu dan dorongan dari suami atau keluarga diharapkan ibu mau menyusui bayinya sendiri. Sehingga ibu bisa memberikan ASInya dan tidak terjadi bendungan ASI. 
Adanya hubungan antara motivasi pada ibu nifas untuk menyusui bayinya dengan kejadian bendungan ASI, disebabkan karena hampir seluruh ibu nifas responden mempunyai motivasi yang baik untuk menyusui bayinya sehingga ibu tidak terjadi bendungan ASI.

\section{KESIMPULAN DAN SARAN}

\section{Kesimpulan}

Ada hubungan antara motivasi pada ibu nifas untuk menyusui bayinya dengan kejadian bendungan ASI

\section{Saran}

1. Bagi Keluarga atau Masyarakat Untuk masyarakat khususnya keluarga untuk selalu memberikan dukungan agar ibu tetap menyusui bayinya meskipun ASI belum keluar dengan cara memberi semangat dan dorongan pada ibu.

2. Bagi Tenaga Kesehatan Bagi tenaga kesehatan terutama bidan diharapkan mampu melakukan KIE tentang pentingnya cara menyusui yang benar secara benar, sehingga dapat meningkatkan motivasi ibu sebagai orang tua untuk menyusui bayinya.

3. Bagi Peneliti Selanjutnya

Hendaknya penelitian ini dapat dijadikan data awal penelitian, untuk dapat dikembangkan lebih luas dan mengambil sampel lebih banyak sehingga hasilnya lebih representatif

\section{DAFTAR PUSTAKA}

\section{Arikunto, S. 2003. Prosedur Penelitian, Suatu Praktek. Jakarta: Bina Aksara}

\section{Arikunto, S. 2006. Prosedur Penelitian Suatu Pendekatan Praktik. Jakarta: Rineka Cipta.}

Depkes RI. 2006. Penelitian Bendungan ASI. Jakarta. Depkes RI

Farrer, Helen. 2001. Perawatan Maternitas Edisi 2. Jakarta :EGC

Hamzah. 2007. Teori Motivasi dan Pengukurannya. Jakarta:Bumi Aksara

Handoko. 1998. Buku Ajar Keperawatan Maternitas. Jakarta. YBP-SP.

Koentjaraningrat. 1997. Metode Penelitian Masyarakat. Gramedia : Jakarta

Mochtar, R. 1998. Sinopsis Obstetri, Obstetri Fisiologi, Obstetri Patologi, bagian 1. EGC, Jakarta.

Nursalam. 2008. Konsep dan Penerapan Metodologi Penelitian Ilmu Keperawatan. Salemba Medika. Jakarta.

Nursalam dan Siti Pariani. 2001. Pendekatan Praktis dan Metodologi Riset Keperawatan. Sagung Seto. Jakarta. 
Notoatmodjo. 2003. Metodologi Penelitian Kesehatan. Rineka Cipta. Jakarta.

Sardiman. 1996. Interaksi dan Motivasi Belajar Mengajar. Jakarta: Raja Grafindo

Soetjiningsih. 1997. ASI: Petunjuk Untuk Tenaga Kesehatan. Jakarta

Sutrisno. 2005. Statistik Jilid 2. Yogyakarta: Andi Offset

Usman, Husaini. 2006. ManajemenTeori, Praktik dan Riset Pendidikan. Bumi aksara: Jakarta 